\title{
若年者における顎関節円板前方転位症例に対する治療法の検討
}

\author{
甲斐裕之・山崎要一*・甲斐貞子・田代英雄
}

\section{Evaluation of the treatments in young people with an anteriorly displaced disc of the TMJ}

\author{
Hiroyuki KaI • Youichi YAmasaki* • Sadako KAI • Hideo TASHIRo
}

\begin{abstract}
The effects of methods which were intended to reduce the anteriorly displaced disc and to maintain it in the correct position were investigated for young patients under 19 years of age with the anteriorly displaced disc of the temporomandibular joint (TMJ). Seventeen patients were treated by means of an occlusal splint only, 5 prosthodontic treatment following splint therapy, and 4 Bionator following splint therapy. Those patients were observed for more than 6 months. Discs in 10 patients of anterior displacement were reduced by mandibular manipulation before various treatments. The results were as follows;
\end{abstract}

1. Splint

All cases were treated with anterior repositioning splints. Although the effectiveness was observed concerning the pain at the affected joint, there were no cases whose disc was still reduced when the splint was removed.

2. Prosthodontic treatment following splint therapy

There were 2 cases whose disc was completely reduced and 3 cases whose reduced disc was displaced again after the prosthodontic treatment.

3. Bionator therapy following splint therapy

There was decrease in over jet and over bite owing to the increase in the vertical occlusal height in all 4 cases. The complete reduction of the disc was achieved in three cases upon removal of a Bionator and one side in a bilateral case. There was no recurrence of pain of the joint and masticatory muscles or displacement of the disc.

Although it was considered that splint treatment is effective to eliminate pain and reduce the disc while the splint was applied, it seems necessary for the following final occlusal reconstruction after splint therapy to prevent recurrence of displacement. The cause of the recurrence of displacement in prosthodontic cases was thought to be the disharmony between the occlusion and the function of the TMJ and it seems difficult to determine the occlusion by irreversible prosthodontic treatment during the growing stage in young patients.

On the other hand, Bionator resolved pain at the TMJ and masticatory muscles, and maintained the proper position of the disc. It is thought that the bionator can change the occlusion continuously utilizing the inherent eruptive force of the teeth in young people in harmony with the function of the TMJ. Furthermore, it seems to direct the disturbed dento-

九州大学歯学部第 1 口腔外科学教室

（主任：田代英雄教授）

* 九州大学歯学部小児㐘科学教室 (主任：中田 稔教授)

First Department of Oral Surgery, Faculty of

Dentistry, Kyushu University (Chief: Prof. Hi- deo Tashiro)

* Department of Pediatric Dentistry, Faculty of Dentistry, Kyushu University (Chief: Prof. Minoru Nakata)

受付日: 平成 3 年 9 月 6 日 
maxillary development by various methods toward the proper one.

Key words: anteriorly displaced disc of the TMJ (顎関節円板前方転位), young people（若 年者), Bionator (バイオネーター)

緒

言

顎関節症患者のなかでは，閉口時の関節円板の前方転 位を示すいわゆる顎関節症 III 型（顎関節研究会の顎関節 症分類案 $\left.{ }^{1}\right)$ 症例が大きな比率を占めているといわれて いる2 5). その転位の 原因はまだあきらかにされてはい ないものの, 咬合の関与が大さいことが指摘されている. 治療は, 関節円板を正常位置に整位させ, 安定させたう えで関節円板転位の再発を防ぐために咬合の再構成が必 要であることが多い. しかしながら20歳未満のいわゆる 若年者の場合，顎骨の成長，歯の萌出の途中であること が多く, 補経処置などによる顎位の決定がその後の成長 に調和してゆく保証はなく，非可逆的な治療による永久 的な顎位の決定は困難であると考学られる。したがって 若年者に対してはこれらを考虑した治療が望まれる。今 回，若年者顎関節症のらち関節円板前方転位と診断され た症例に対し，関節円板整位後，その状態を維持安定さ せる目的で著者らが行った各種の治療法について検討し たので報告する.
対

象（表 1)

1987年 1 月より 1989年12月までに当科を初診した 20 歳 未満の顎関節症患者のうち, 臨床診断, あるいは上下顎 関節腔単一造影所見, 顎関節矢状断 CT 撮影により関 節円板前方転位と診断された症例で, 各種治療終了後よ り 6 か月以上経過観察が可能であった 26 症例である. 年 齢は最低 7 歳, 最高19歳であり, 平均年齢は 15.6 歳であ った，性別は，男性 5 症例，女性 21 症例であった。この らち復位のある関節円板前方転位症例が16例, 徒手的円 板整位術により関節円板の整位が可能であった復位のな い関節円板前力転位症例が10例であった。

\section{治療方法（図 1，表 2）}

\section{1. 復位のある関節円板前方転位症例}

1 例を除く 15 症例に対して, 開口時, 閉口時ともにク リックの生じない下顎前方位にて上顎に下顎前方整位型 スプリントを装着させ， $1 \sim 2$ 週間間隔での再来のたび にその位置でのクリックの有無を調べ少しずつ下顎を後 退させ,クリックが発生しない位置でスプリントを調整

表 1 刘象症例

20 歳未満の顎関節円板前方転位患者 26 症例

（各種治療開始より6か月以上経過観察が可能でをった症例）

\begin{tabular}{|c|c|c|c|c|c|c|}
\hline 性別 & 男： & 5 例 & 女 2 & 1例 & & \\
\hline 年齢 & 最低 & 7 歲 & 最高 & 19祡 & 平均 & 15.6藏 \\
\hline \multicolumn{7}{|c|}{ 円板転位の種類 } \\
\hline \multicolumn{3}{|c|}{ 復位のある前力転位 } & \multicolumn{4}{|l|}{ 16例 } \\
\hline \multicolumn{3}{|c|}{ 復位のない前方転位。 } & \multicolumn{4}{|l|}{ 10例 } \\
\hline
\end{tabular}

表 2 治療内行

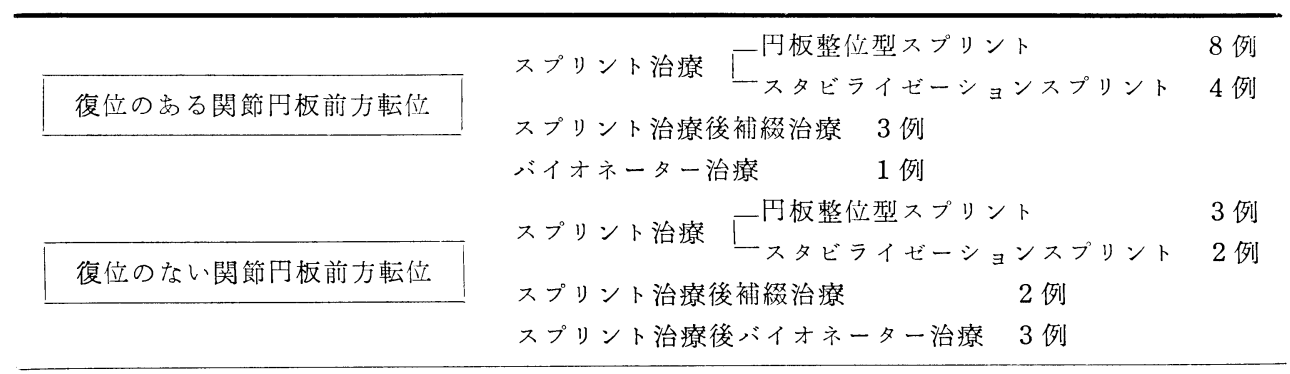




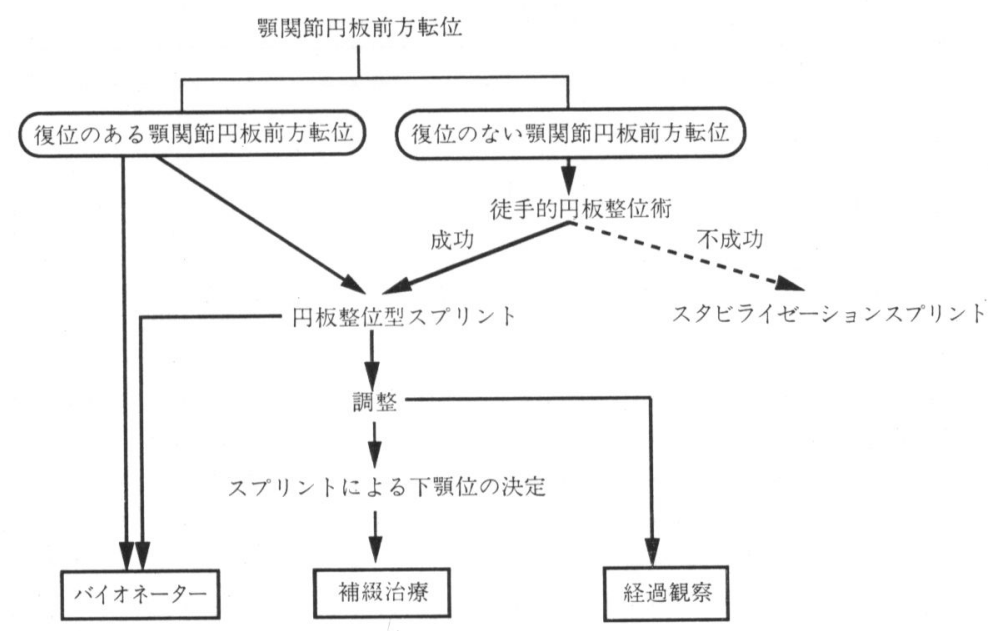

図 1 治療法

した。その結果，もとの中心咬合位にて開閉口させても クリックの生じない 4 症例に対しては, その位置にてス プリントをスタビライゼーション型スプリントに変更 し,さらに経過の観察を行い装着時間を少しずつ短縮 し，最終的にはスプリントを装着させずに経過観察を行 った。ささらに，もとの中心咬合位に戻すとクリックの発 生する11症例のうち 3 症例に対しては, スプリントによ る関節円板が整位した状態での最小前方下顎位を決定 し，最終的に補綴による咬合再構成を行った。スプリン トによる治療を行わなかった 1 例は初診時, 前歯部反対 咬合であったため。まず上颓切歯をりンガルアーチを用 い, 唇側へ傾斜させ正被蓋を得た後に, バイオネーター に上る治療を行った。 バイオネーターは, 犬歯, 且歯部 の歯牙の挺出を生じさせ，下顎の前方移動を起こさせる 目的で，上下中側切歯のみと接触するレジン床を介在さ せ犬歯以後の上下歯牙を離開させた。 さらに上下中, 側 切歯間のレジン床の後方に, 頓舌的にバクチネーターベ ンド怙よび舌側板を付与させ，頪粘膜，舌が歯牙の挺出 を妨げないようにし，またオーバージェットの減少をは かるため上顎前歯部に唇側線を設けた。装着時の下顎の 位置は関節円板の転位を起こさない最小の前方位とし， バイオネーターの装着は夜間のみとした（写真 1$)$.

\section{2. 復位のない関節円板前方転位症例}

まず徒手的円板整位術で関節円板の整位を行った後, 下䫇前方整位型スプリントを装着させた。再来時，顎関 節がクローズドロック状態であれば，そのたびごとに徒 手的円板整位術を行い関節円板を整位した，再来時にク ローズドロック所見がなければ，その後の治療は復位の ある関節円板前方転位の治療方法に準じて行った。内容 は下頱前方整位型スプリントによる経過観察 3 例，下頱 前方整位型スプリントを調整しもとの中心咬合位に戻

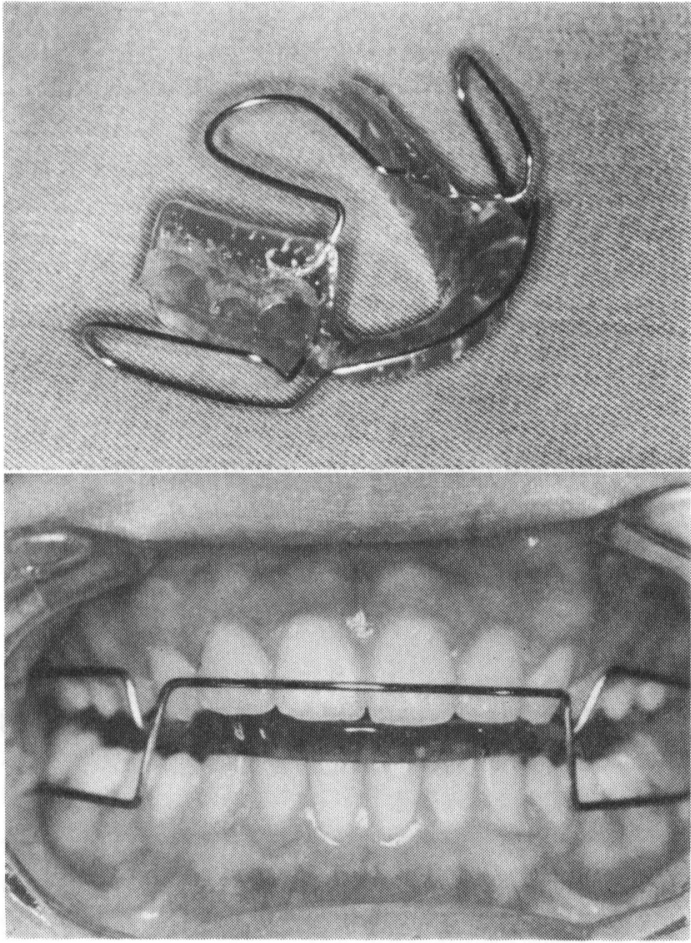

写真 1 上：バイオネーター装置, 下：バイオネー タ一口腔内装着時正面

し，さらにスプリント非装着にて経過観察を行った症例 2 例, スプリントによる下顎位の決定の後, 補綴処置を 行った症例が 2 例，スプリントによって関節円板の整位 維持を行った後, 臼歯部の歯牙挺出を図るためにバイオ 
表 3 スプリント治療群における治療前後の変化

\begin{tabular}{|c|c|c|c|c|c|c|c|c|c|}
\hline \multirow{2}{*}{ 症例 } & \multirow{2}{*}{ 性別 } & \multirow{2}{*}{ 年齢 } & \multirow{2}{*}{ 部位 } & 疼 & 痛 & \multirow{2}{*}{$\begin{array}{c}\text { 観察期間 } \\
\text { (月) }\end{array}$} & \multirow{2}{*}{$\begin{array}{c}\text { 最終* } \\
\text { スプリント }\end{array}$} & \multirow{2}{*}{$\begin{array}{l}\text { 開口域 } \\
(\mathrm{mm})\end{array}$} & \multirow{2}{*}{ 態** } \\
\hline & & & & 顎関節部 & 咀嚼筋 & & & & \\
\hline 1 & 男 & 17 & 左 & $\rightarrow-$ & $-\rightarrow-$ & 24 & $\mathrm{~S}$ & $50 \rightarrow 52$ & $W \rightarrow W$ \\
\hline 2 & 女 & 18 & 左 & $\rightarrow-$ & $\rightarrow-$ & 8 & $\mathrm{R}$ & $43 \rightarrow 45$ & $\mathrm{~W} \rightarrow \mathrm{W}$ \\
\hline 3 & 女 & 13 & 左 & $\rightarrow-$ & $\rightarrow-$ & 8 & $\mathrm{R}$ & $43 \rightarrow 51$ & $\mathrm{~W} \rightarrow \mathrm{W}$ \\
\hline 4 & 女 & 19 & 左 & $\rightarrow-$ & $-\rightarrow+$ & 7 & $\mathrm{R}$ & $51 \rightarrow 48$ & $W \rightarrow W$ \\
\hline 5 & 女 & 11 & 両側 & $-\rightarrow-$ & $-\rightarrow-$ & 8 & $\mathrm{~S}$ & $46 \rightarrow 46$ & $\mathrm{~W} \rightarrow \mathrm{W}$ \\
\hline 6 & 女 & 15 & 左 & $\rightarrow-$ & $-\rightarrow-$ & 13 & $\mathrm{R}$ & $46 \rightarrow 46$ & $\mathrm{~W} \rightarrow \mathrm{W}$ \\
\hline 7 & 女 & 13 & 左 & $-\rightarrow-$ & $-\rightarrow-$ & 12 & $\mathrm{R}$ & $47 \rightarrow 47$ & $\mathrm{~W} \rightarrow \mathrm{W}$ \\
\hline 8 & 男 & 17 & 右 & $-\rightarrow-$ & $+\rightarrow+$ & 22 & $\mathrm{R}$ & $51 \rightarrow 51$ & $\mathrm{~W} \rightarrow \mathrm{W}$ \\
\hline 9 & 女 & 18 & 左 & $+\rightarrow-$ & $+\rightarrow-$ & 20 & $\mathrm{R}$ & $45 \rightarrow 46$ & $\mathrm{~W} \rightarrow \mathrm{W}$ \\
\hline 10 & 女 & 18 & 右 & $+\rightarrow-$ & $+\rightarrow-$ & 9 & $\mathrm{R}$ & $43 \rightarrow 46$ & $\mathrm{~W} \rightarrow \mathrm{W}$ \\
\hline 11 & 女 & 16 & 左 & $+\rightarrow-$ & $-\rightarrow+$ & 7 & $\mathrm{~S}$ & $39 \rightarrow 42$ & $\mathrm{~W} \rightarrow \mathrm{W}$ \\
\hline 12 & 男 & 17 & 左 & $+\rightarrow-$ & $+\rightarrow+$ & 26 & $\mathrm{~S}$ & $49 \rightarrow 46$ & $\mathrm{~W} \rightarrow \mathrm{W}$ \\
\hline 13 & 女 & 16 & 左 & $+\rightarrow-$ & $+\rightarrow-$ & 11 & $\mathrm{R}$ & $29 \rightarrow 49$ & 柁 $\mathrm{WO} \rightarrow \mathrm{W}$ \\
\hline 14 & 女 & 18 & 左 & $+\rightarrow-$ & $+\rightarrow-$ & 6 & $\mathrm{~S}$ & $38 \rightarrow 50$ & $\hbar \mathrm{WO} \rightarrow \mathrm{W}$ \\
\hline 15 & 女 & 19 & 左 & $-\rightarrow-$ & $\rightarrow-$ & 20 & $\mathrm{R}$ & $35 \rightarrow 45$ & $\hbar \mathrm{WO} \rightarrow \mathrm{W}$ \\
\hline 16 & 男 & 15 & 右 & $-\rightarrow-$ & $-\rightarrow+$ & 21 & $\mathrm{R}$ & $27 \rightarrow 47$ & $\hbar \mathrm{WO} \rightarrow \mathrm{W}$ \\
\hline 17 & 女 & 18 & 左 & $+\rightarrow-$ & $+\rightarrow-$ & 7 & $\mathrm{~S}$ & $29 \rightarrow 55 \rightarrow 33$ & $\downarrow \mathrm{WO} \rightarrow \mathrm{W} \rightarrow \mathrm{WO}$ \\
\hline
\end{tabular}

* $\mathrm{R}$ ：下顎前方整位型スプリント

$\mathrm{S}$ : スタビライゼーションスプリント
** $\mathrm{W}$ : 復位のある関節円板前方転位 WO : 復位のない関節円板前方転位 动：徒手的円板整位術施行例
ネーターによる治療を行った症例が 3 例であった。な打 下頸前方整位型スプリントは, 夜間就寝中はもちろんの こと食事時以外可能な限り長時間装着するよう飞指導し たが，特に関節円板整位術により関節円板が整位した症 例に対しては，少なくとも 3 日間 24 時間スプリントを装 着するように指示した。

\section{結}

\section{果}

\section{1. スプリント治療後 6 か月以上経過観察した 17 症例} の治療前後の変化 (症状, 病態の判定はスプリン 卜非装着時）（表 3）

最低年齢11歳，最高年齢19歳で，平均年齢は16.4歳で あった，男性 4 症例，女性13症例であった。初診時の病 態は復位のある関節円板前方転位（以下Wと略する） 12 例，復位のない関節円板前方転位（以下WO と略する） 5 例であった。観察期間は最短 6 か月, 最長 26 力月で, 平均13.5か月であった。顎関節痛は治療前 7 例に認めら れたが，スプリント治療中に全症例に沶いて消失した。 咀嚼筋圧痛は治療前 7 例に認められたが，そのうち 5 例 で消失し， 2 例で不变であった，一方，治療前咀嚼筋圧 痛が認められなかった症例でスプリント治療中，3例に 疼痛が発現した。平均最大開口域の変化は復位のある関
節円板前方転位症例では初診時 $46.1 \mathrm{~mm}$, 治療後 47.2 $\mathrm{mm}$ であった。 また，復位のない関節円板前方転位例で は, 再発の認められた 1 例を除き平均最大開口域は初診 時 $32.3 \mathrm{~mm}$ から最終観察時 $47.8 \mathrm{~mm}$ 之, $15.5 \mathrm{~mm}$ の 増大が認められた。

初診時より最終観察時の関節円板の病態の変化は, 変 化な L12例 $(W \rightarrow W)$, 改善 4 例 $(W O \rightarrow W)$, 再発 1 例 $(\mathrm{WO} \rightarrow \mathrm{W} \rightarrow \mathrm{WO})$ でスプリント非装着時に 完全に 関節 円板が整位している症例はなかった。特に症例 $1 ， 5$, 11，12，14は下顎前方整位型スプリントをスタビライゼ ーション型スプリントに变え，さらにスプリント非装着 状態でも関節円板の整位が得られたが，それは一時的で あり，しばらくすると患側のクリック音が生じたため, 再びスプリント治療を頻回に行わざるを得なかった。 ま た症例17はスプリント非装着時にも関節円板の整位が得 られたが経過観察中に患側のクリック音が生じ，まもな く関節円板は復位のない前方転位に移行した。

\section{2. 補緅治療後 6 か月以上経過観察した 5 症例の治療 前後の変化 (表 4 )}

最低年齢13歳，最高年龄17歳で，平均年齢は15.8歳で あった。 また症例はすべて女性であった，初診時の病態 はWが 3 症例，WOは 2 症例であった。顎関節痛は治療 前 4 例飞認められ，スプリント治療後に全症例で消失し 
表 4 スプリント後補経治療群における治療前後の変化

$\mathrm{A}$ ：初診時, $\mathrm{B} ：$ スプリント治療後, C : 補経後

\begin{tabular}{|c|c|c|c|c|c|c|c|c|c|}
\hline \multirow{3}{*}{ 症例 } & \multirow{3}{*}{ 性別 } & \multirow{3}{*}{ 年歯 } & \multirow{3}{*}{ 部位 } & \multicolumn{2}{|c|}{ 疼痛 } & \multirow{3}{*}{$\begin{array}{l}\text { 補綴治療後の観 } \\
\text { 祭期間 (月) }\end{array}$} & $\begin{array}{l}\text { 開口域 } \\
(\mathrm{mm})\end{array}$ & \multicolumn{2}{|c|}{ 病態 } \\
\hline & & & & 顎関節部 & 咀嚼筋 & & & & \\
\hline & & & & A B C & A $\quad$ B $\quad$ C & & A $\quad$ B $\quad$ C & A & $\mathrm{B}^{*} \mathrm{C}$ \\
\hline 1 & 女 & 16 & 右 & $+\rightarrow-\rightarrow-$ & $-\rightarrow-\rightarrow-$ & 9 & $45 \rightarrow 46 \rightarrow 46$ & W & $\rightarrow \mathrm{N} \rightarrow \mathrm{N}$ \\
\hline 2 & 女 & 13 & 右 & $-\rightarrow+\rightarrow-$ & $+\rightarrow+\rightarrow+$ & 12 & $50 \rightarrow 50 \rightarrow 50$ & $\mathrm{~W}$ & $\rightarrow \mathrm{N} \rightarrow \mathrm{N}$ \\
\hline 3 & 女 & 16 & 左 & $+\rightarrow-\rightarrow+$ & $-\rightarrow-\rightarrow-$ & 18 & $40 \rightarrow 50 \rightarrow 24$ & $\mathrm{~W}$ & $\rightarrow \mathrm{N} \rightarrow \mathrm{WO}$ \\
\hline 4 & 女 & 17 & 右 & $+\rightarrow-\rightarrow+$ & $\rightarrow \rightarrow-\rightarrow$ & 9 & $21 \rightarrow 45 \rightarrow 25$ & $\hat{W W O}$ & $\rightarrow \mathrm{N} \rightarrow \mathrm{WO}$ \\
\hline 5 & 女 & 17 & 右 & $+\rightarrow-\rightarrow-$ & $-\rightarrow-\rightarrow-$ & 24 & $25 \rightarrow 46 \rightarrow 30$ & $\xi W C$ & $\rightarrow \mathrm{W} \rightarrow \mathrm{WO}$ \\
\hline
\end{tabular}

$\mathrm{W}:$ 復位のある関節円板前力転位

WO : 復位のない関節円板前方転位

$\mathrm{N}:$ 関節円板の転位なし

坅：徒手的円板整位術施行例

*：スプリント装着時

表 5 スプリント後バイオネーター治療群における治療前後の変化

$\mathrm{A}$ ：初診時, $\mathrm{B}$ ：スプリント治療後, C : バイオネーター後

\begin{tabular}{|c|c|c|c|c|c|c|c|c|c|c|}
\hline \multirow{3}{*}{ 症例 } & \multirow{3}{*}{ 性別 } & \multirow{3}{*}{ 年粜合 } & \multirow{3}{*}{ 部位 } & \multicolumn{2}{|c|}{ 疼痛 } & \multirow{3}{*}{$\mid \begin{array}{l}\text { ハイオネ一 } \\
\text { ター観察期 } \\
\text { 間（月） }\end{array}$} & \multirow[t]{2}{*}{$\begin{array}{l}\text { 開口域 } \\
(\mathrm{mm})\end{array}$} & \multirow[t]{2}{*}{ 病態 } & \multirow{2}{*}{$\begin{array}{l}\text { オーバー } \\
\text { シェット } \\
(\mathrm{mm})\end{array}$} & \multirow{2}{*}{$\begin{array}{l}\text { オーバー } \\
\text { パイ } \\
(\mathrm{mm})\end{array}$} \\
\hline & & & & 顎関節部 & 咀嚼筋 & & & & & \\
\hline & & & & A $\quad$ B $\quad$ C & A B C & & A $\quad$ B $\quad$ C & A & A C & A C \\
\hline 1 & 男 & 11 & 右 & $+\rightarrow-\rightarrow-$ & $-\rightarrow-\rightarrow-$ & 18 & $29 \rightarrow 45 \rightarrow 45$ & $\Sigma \mathrm{W} \mathrm{W} \rightarrow \mathrm{N} \rightarrow \mathrm{N}$ & $3.5 \rightarrow 2.0$ & $2.5 \rightarrow 1.5$ \\
\hline 2 & 女 & 14 & 右 & $-\rightarrow-\rightarrow-$ & $-\rightarrow-\rightarrow-$ & 8 & $35 \rightarrow 50 \rightarrow 50$ & $\varsigma^{2} \mathrm{WO} \rightarrow \mathrm{N} \rightarrow \mathrm{N}$ & $7.0 \rightarrow 4.5$ & $2.0 \rightarrow 1.5$ \\
\hline 3 & 女 & 16 & 右 & $+\rightarrow-\rightarrow-$ & $-\rightarrow-\rightarrow-$ & 15 & $40 \rightarrow 55 \rightarrow 58$ & $i \sim \mathrm{WO} \rightarrow \mathrm{N} \rightarrow \mathrm{N}$ & $5.5 \rightarrow 2.5$ & $3.0 \rightarrow 1.5$ \\
\hline 4 & 女 & 7 & 両㑡 & $+\rightarrow-$ & $-\rightarrow-$ & 26 & $41 \rightarrow 48$ & $\rightarrow \mathrm{W}^{*}$ & $-2.0 \rightarrow 1.5$ & $2.0 \rightarrow 3.5$ \\
\hline
\end{tabular}

$\mathrm{W}$ : 復位のある関節円板前方転位

WO : 復位のない関節円板前方転位

$\mathrm{N}:$ 関節円板の転位なし

约: 徒手的円板整位術施行例

* : 治療前両側クリックが認められたが，治療中，片側のクリックが消失した.

たが補綴治療後 2 例に再発した，巡にスプリント治療中 に出現し, 補経治療後に消失した症例が 1 例認められ た．咀嚼筋圧痛はスプリント治療後 1 例のみに認められ たが, 補経治療後にも認められ, その程度は増強した。

初診時, スプリント治療後, および補経処置後の関節 円板の病態変化は，関節円板完全整位（以下 $\mathrm{N}$ と略す る) 2 例 $(\mathrm{W} \rightarrow \mathrm{N} \rightarrow \mathrm{N})$, 再発 2 例 $(\mathrm{W} \rightarrow \mathrm{N} \rightarrow \mathrm{WO}, \mathrm{WO}$ $\rightarrow \mathrm{W} \rightarrow \mathrm{WO})$, 増悪 1 例 $(\mathrm{W} \rightarrow \mathrm{N} \rightarrow \mathrm{WO}$ ）であった.

\section{3. バイオネーター治療後 6 か月以上経過観察した 4 症例の治療前後の变化 (症状, 病態の判定はバイ オネーター非装着時）(表 5)}

最低年齢は 7 歳, 最高年齢は16歳で, 平均年舲は 12.0 歳であった。 また男性 1 例，女性 3 例であった，初診時
の病態はWが 1 例，WOが 3 例であった．経過観察期間 は最短 6 か月, 最長 26 月であった。顎関節痛は初診時 3 例に認められたがスプリント治療中, 全例で消失し, バイオネーター治療中も疼痛の発現は認めなかった。治 療前咀嚼筋圧痛を有する症例はなく，また逆に治療中， 治療後に疼痛が出現した症例もなかった。

初診時, スプリント治療後, およびバイオネーター治 療後の関節円板の病態変化は完治 3 例 $(\mathrm{WO} \rightarrow \mathrm{N} \rightarrow \mathrm{N})$ であった，残りの 1 例も治療前, 両側の相反性クリック が存在したが, 治療中, 開口域の減少なしに片側のクリ ックが消失した。 セファロ分析にて全症例で咬合高径の 增加が認められた（図2〜5). 


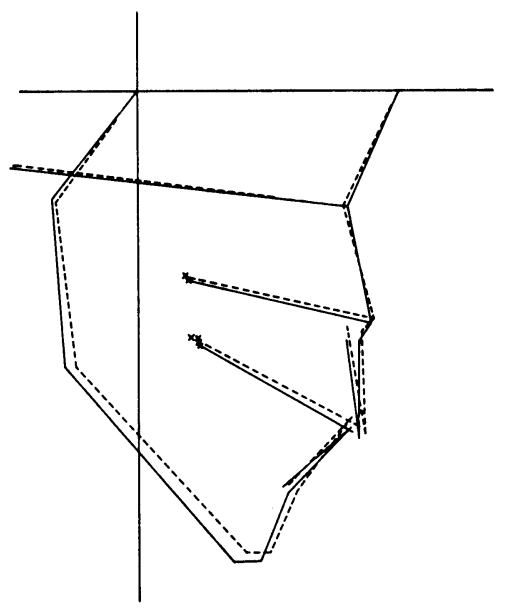

症例 1 男性

- - - 治療前 (11歳 8 力月)

治療後（12歳 4 か月）

\begin{tabular}{l|r|r}
\hline & 治療前 & 治療後 \\
\hline SNA & 81.4 & 81.0 \\
SNB & 75.7 & 74.6 \\
mandibular pl. & 39.3 & 41.3 \\
occlusal pl. & 20.6 & 22.7 \\
U 1 to FH pl. & 106.7 & 104.0 \\
L 1 to mandibular pl. & 86.9 & 90.6 \\
\hline
\end{tabular}

図 2

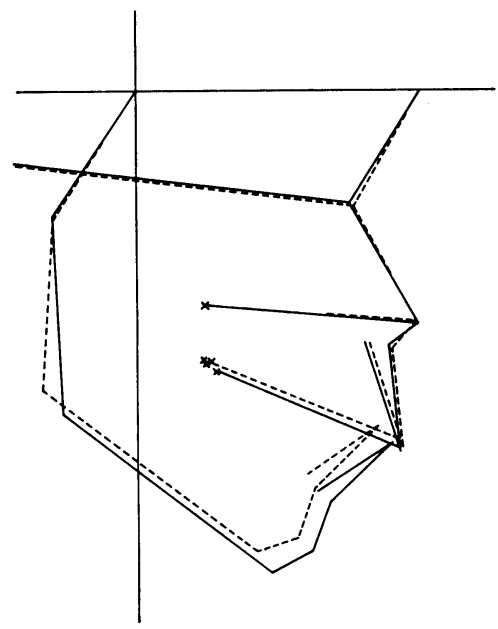

症例 2 女性

- - - 治療前 (14歳 2 力月)

治療後（14歳 9 力月）

\begin{tabular}{l|r|r}
\hline & 治療前 & 治療後 \\
\hline SNA & 83.4 & 82.8 \\
SNB & 74.9 & 77.5 \\
mandibular pl. & 27.4 & 27.2 \\
occlusal pl. & 15.4 & 16.4 \\
U 1 to FH pl. & 114.9 & 114.9 \\
L 1 to mandibular pl. & 110.6 & 112.8 \\
\hline
\end{tabular}

図 3

症例

患 者 : 13歳 女性.

初診日：1988年11月日。

主 訴: 間欠的な開口障害.

診 断: 右側復位のある靧関節円板前方転位（間欠的 クローズドロック).

初診時の現症ならびに治療経過 : 初診時最大開口域は 上下中切歯間で $50 \mathrm{~mm}$ を示し, 開口 $40 \mathrm{~mm}$ の時点と 閉口終末付近で相反性クリッキングを認め, 右側咬筋に 軽度の圧痛が認められた。 上下前歯切端位でクリッキン

グが消失することを確認し，その位置にて下䫇前方整位 型スプリントを装着させ, 再来のたびにスプリントを調 整した。 1 か月後, スプリント非装着時にもクリックは 消失しており, 両側曰歯部に離開が認められた。ささらに その顎位を保持するようにスプリントを調整した。関節 円板の再転位所見が認められなかったため, 初診時より 3 か月後, 両側下顎部の臼歯部の5蝕治療を兼㸚, $\overline{765 \mid 567}$ の歯牙にアンレーを装着した（写真 2). ア ンレー装着 8 か月後関節円板の再転位所見は認められな かったが, 右側の咬筋痛の増大が認められ，12か月後， 右側咬筋の圧痛は不变のまま前歯部のわずかな開咬が出 現した（写真了）. 


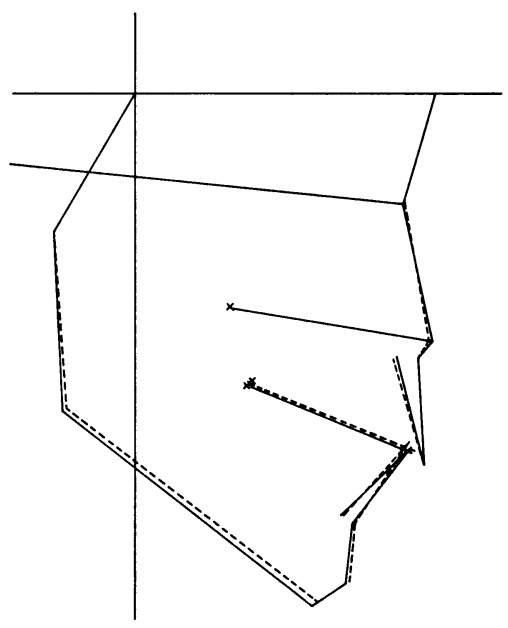

症例 3 女性

- - - 治療前 (16歳 0 力月) 徒手的円板整位術後 治療後 (16歳 6 か月)

\begin{tabular}{l|r|r}
\hline & 治療前 & 治療後 \\
\hline SNA & 86.5 & 86.7 \\
SNB & 79.5 & 79.4 \\
mandibular pl. & 31.0 & 31.9 \\
occlusal pl. & 16.3 & 16.9 \\
U 1 to FH pl. & 111.3 & 109.6 \\
L 1 to mandibular pl. & 95.2 & 97.6 \\
\hline
\end{tabular}

図 4

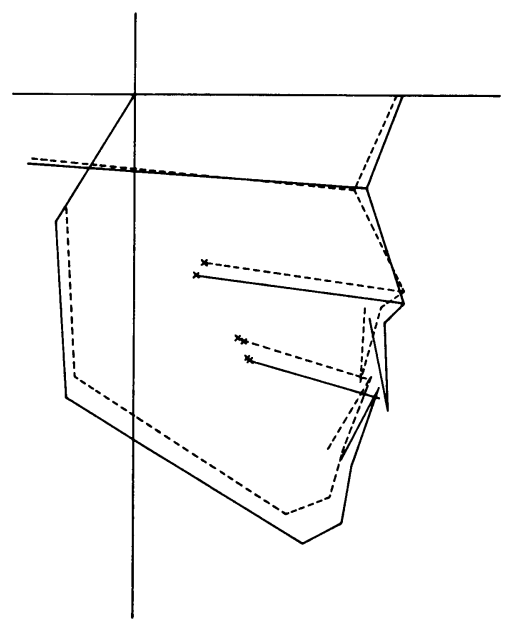

症例 4 女性

- - - 治療前 ( 7 歳 5 力月)

治療後（9歳 7 か月）

\begin{tabular}{l|r|r}
\hline & 治療前 & 治療後 \\
\hline SNA & 86.1 & 85.7 \\
SNB & 81.8 & 82.3 \\
mandibular pl. & 25.1 & 24.6 \\
occlusal pl. & 11.3 & 11.6 \\
U 1 to FH pl. & 92.0 & 105.5 \\
L 1 to mandibular pl. & 89.9 & 88.6 \\
\hline
\end{tabular}

患 者: 16歳 女性.

初診日: 1989年 6 月回日。

主 訴: 最大開口時扣よび咀嚼時の左側顎関節部の疼 痛.

診 断：左側復位のない靧関節円板前方転位

初診時の現症ならびに治療経過：初診時最大開口域は 上下中切歯間にて $40 \mathrm{~mm}$ で, 最大開口時下罘は左側に わずかに偏位した。同時に左側䫇関節部に鈍痛を自覚し

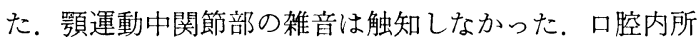
見では閉口時, オーバージェットは $5.5 \mathrm{~mm}$, オーバー バイトは $3.5 \mathrm{~mm}$ であった（写真 4$)$ ．エックス線所見 では硬組織の構造的, 形態的变化は認めなかったが, 経
頭蓋撮影法にて両側下罘頭は最大開口時, 関節結節直下 に位置し運動制限が認められた（写真 5 )。 上記診断に て左側靧関節部に対し徒手的円板整位術を行ったとこ ろ，整復音ととも㵊大開口域が $55 \mathrm{~mm}$ に増加し，同 時に最大開口時の左側頡関節部の疼痛が消失した。下顎 前歯切端位にて下顎前方整位型スプリントを 1 週間 24 時 間装着させたところ, スプリント非装着時にもクローズ ドロックの所見は認めなくなった。 また同時に下顎はや や前方位にて固定され，両側臼歯部が離開した。 さらに 下䋶前方整位型スプリントをバイオネーターに变更し た。 6 か月後, 閉口時オーバージェット $2.5 \mathrm{~mm}$, オー バーバイト $1.5 \mathrm{~mm}$ に減少した（写真 6 ）。また臼歯部 


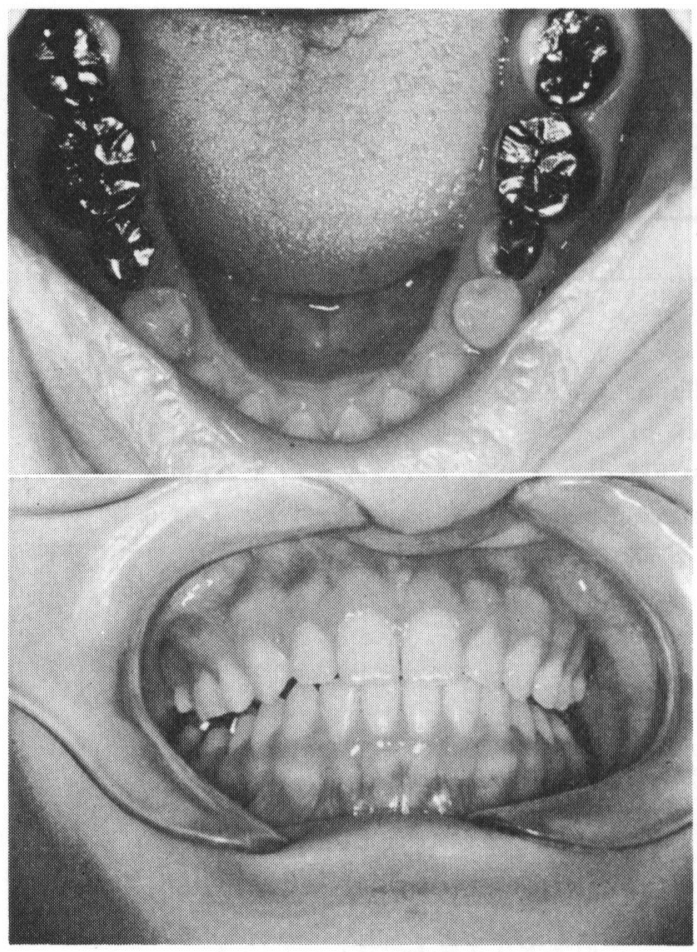

写真 2 上：下顎咬合面, $\overline{765 \mid 567}$ にアンレー装着, 下：アンレー装着時の閉口時口腔内正面

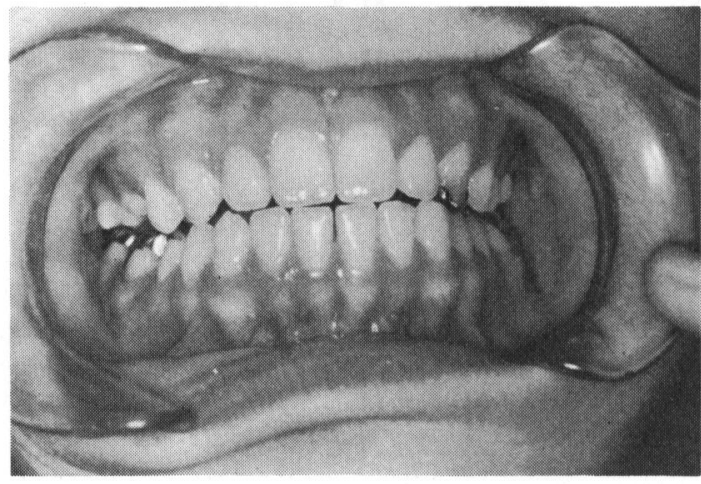

写真 3 アンレー装着12か月後の閉口時口腔内所見 上下中側切菓の離開が認められる。

の挺出により曰歯部の咬合の安定も得られた(写真 7). 最大開口域は $58 \mathrm{~mm}$ となり, 買関節部, 咀嚼筇群の疼 痛は認めなかったため, バイオネーターによる治療を終 了した，その時点でのセファロ分析では，治療前と比較 して臼歯部の歯牙の挺出による咬合高径の増加のため, 下顎の時計まわりの回転が起こり,オーバーバィトの減 少が認められた。 また SNB は汪とんど治療前後で差が

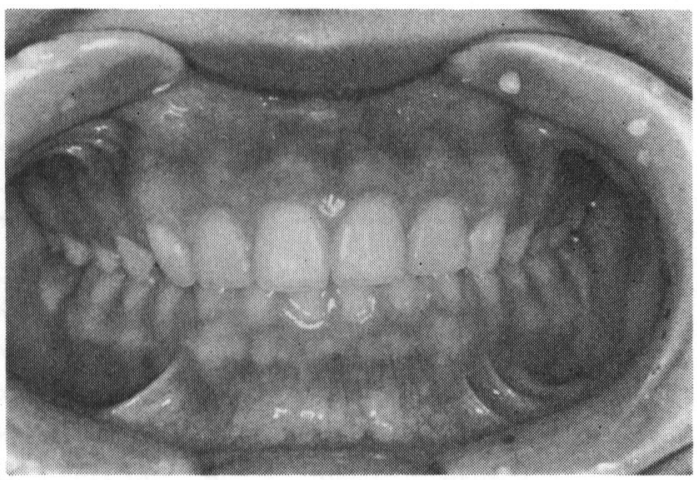

写真 4 初診時の閉口時咬合正面钼 オーパージェット $5.5 \mathrm{~mm}$ ，オーパーパイト 3.5 $\mathrm{mm}$.

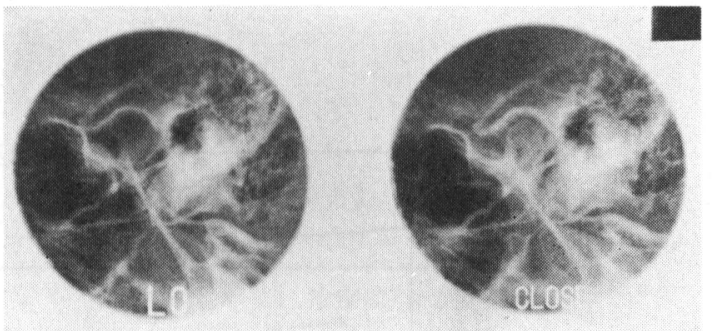

写真 5 左颚関節部の規格経頭蓋撮影エックス線写 真

右が閉口時, 左が最大開口時。

硬組織の変化は認められないが，最大開口時，下 顎頭が関節結節直下に位置し, 運動制限が認められ る。

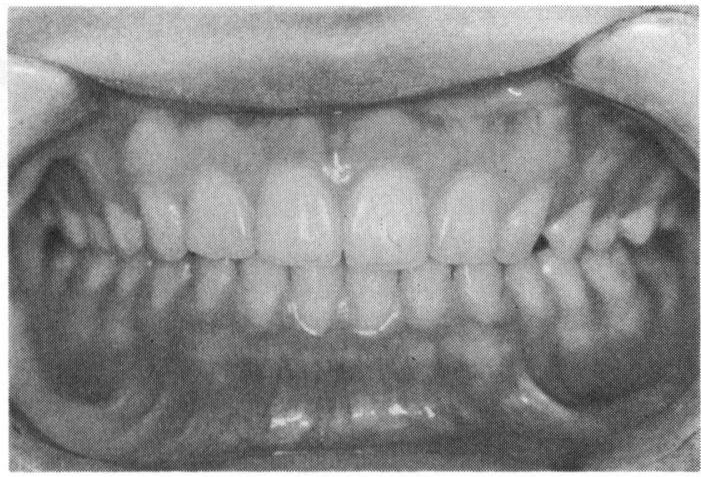

写真 6 バイオネーター治療終了時（治療開始上り 6 か月後）の閉口時咬合正面観 オーバージェット $2.5 \mathrm{~mm}$ ，オーバーバイト 1.5 $\mathrm{mm}$. 


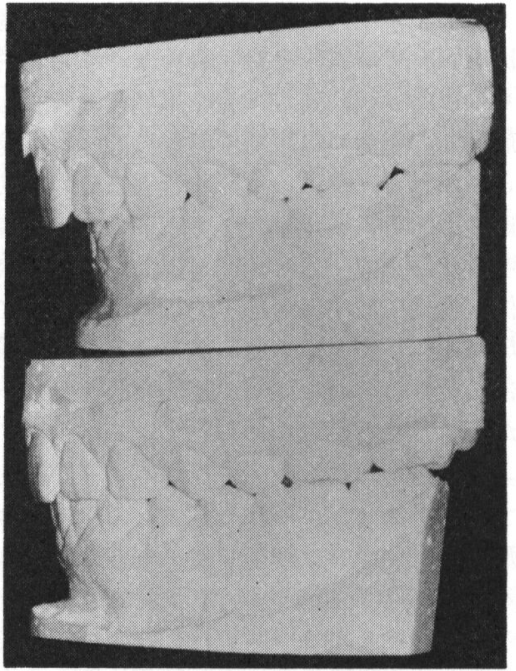

写真 7 スタディモデル左側面観 上：初診時, 下：治療終了時。

なく，下顎の回転に伴う B 点の後退を，下顎全体の前方 移動にて補っているものと思われた。オーバージェット は上下切歯歯軸の傾斜と下顎のわずかな前方移動により 減少が認められた（図 4)。その後 9 か月間経過観察を 行っているが，関節円板転位の再発は認められず，また 関節部の顎運動痛も認められなかった。

\section{考}

\section{察}

顎関節症はその病態からみれば，関節円板が閉口時， 前方に転位しているものが頻度的にいらばん高いとされ ている ${ }^{2 \sim 5)}$ 。さらに著者らが調査した 20 歳未満の顎関節 症患者では，関節円板前方転位と診断されたものが86.6 \%を占め ${ }^{6)}$ ，若年者顎関節症症状のほとんどが関節円板 の転位に起因するといっても過言ではないと思われる. 若年者の関節円板転位症例に抽いても高頻度に顎関節硬 組織の変化が認められ, 高度のものでは下顎頭の低形成 を認めたとの報告もある7)。 したがって，関節円板前方 転位と診断された患者の治療に対しては，関節円板をま ず整位させ，整位した状態を維持するよらに努めること が必要と思われる。このため保存的療法の 1 つと て，スプリント療法がひろく行われている8 11). 復位の ある関節円板前方転位症例の多くは，前方下顎位にて関 節円板を整位させることが可能なため，下顎前方整位型 スプリントを用いその状態を維持する方法か゚行われてい る、さらに関節円板が転位しない範囲で下顎を徐々に後 退させ，もとの咬合位に戻すか，あるいは関節円板が転 位しない下顎位を決定し，最終的に咬合の再構成を行 う。また復位のない関節円板前方転位症例では, 徒手的
円板整位術を行い関節円板を整位させたうえで，復位の ある関節円板前方転位症例と同様に治療を行うとされて いる.

若年者顎関節症の発症については，顎発育の途上とい ら特殊性より，さまざまな原因論があげられているが 12 17), そのなかでも咬合状態と本症発症との関係が最も広 く理解されて扣り，因果関係が強いようである。田口 $ら^{15)}$ ，成ら ${ }^{18)}$ は，若年者顎関節症の患者には，不正咬合 を有する症例が高頻度でみられ，そのなかでも上顎 前 突，過蓋咬合，叢生，下顎前突が多かったと報告してい る。乙かしながら若年者患者の治療に際しては, 咬合に 問題があると思われても，歯牙，顔面を含め成長期にあ ることを念頭に置き，慎重な対応と長期間の経過観察が 必要であると思われる。特に咬合に対する不可逆的な力 法は後の顎発育の障害となりえることも予想され，十分 な計画のもとに行うべきであり安易に行うべきではない と思われる。田口ら ${ }^{19)}$ は，咬合調整などの非可逆的な治 療は第 1 選択とすべきではなく，関節円板を下顎頭の上 に乗せたうえでのスプリント治療による可逆的な治療を 第 1 とすべきであると述べている，成ら ${ }^{18}$ は成長期にあ る患者に対しては，なるべく非可逆的な処置は避け，薬 物療法, スプリント, 理学療法などの保存的療法を選択 している。積極的な治療を行わなくても経過観察のみで 良好な予後の得られるものも含まれていると思われると 述へてているが，顎関節の雑音が存在した症例については 予後調査でもかなりの頻度で雑音が残存している，矢崎 $ら^{8)}$ はクリックに関してはスプリント療法のみでは関節 円板は整位しえなくなっているのではないかと考え，ス プリント療法後には, 関節円板を維持安定させるために 何らかの処置を行い咬合を改善しなければならないと述 ベている.このために治療途中に使用していたスプリン トの臼歯部を切断し，臼歯部の歯牙の挺出をはかること により関節円板の位置を正常に維持した症例を報告し

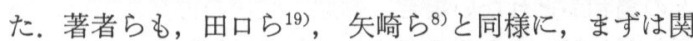
節円板を整位させ，下顎前方整位型スプリントを装着さ せている。しかしながら, スプリントのみの治療を行っ た17例の経過観察でも示されたように，関節円板が整位 した状態でもとの中心咬合位に戻しえた症例は 6 症例の みであった。それらもスプリントを除去してしばらく経 過観察すると，5症例に関節雑音の再発，1例に復位の ない関節円板前方転位によると思われる開口障害が生じ た．残りの症例は，常にある程度下顎を前方位に維持し なければ関節円板の転位を防ぐことが不可能であった。

Lundh ら () $^{9}$ ，相反性クリッキングを有する復位のある 関節円板前方転位症例 24 例に対し， 6 週間24時間下顎前 方整位型スプリントで治療を行っているが，スプリント 除去後11週後に完全に関節円板が整位している症例は 5 症例 $(21 \%)$ にすぎなかったと述べている。また和嶋 $ら^{20)}$ も関節円板転位症例に対して，スプリントを除去後 
に治療前の咬合位に戻すといら理想的な治療はごく限ら れた症例にしかあてはまらないと述べており，スプリン ト除去後の関節円板転位の再発は非常に多いようであ る.このように下顎前方整位型スプリント治療での関節

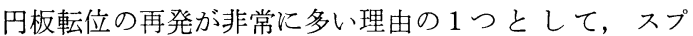
リント自体は咬合を変化させる要素がないことが考えら れる、つまりスプリントを除去した段階では, 関節円板 が転位していたもとの咬合状態に戻っていることにな る。このため関節円板は再びもとの咬合を通じての強い 荷重下に执かれ下顎頭と関節円板との間の安定性を欠く ものと思われる。 したがってスプリントによる関節円板 前方転位症例の治療は根本的な治療ではなく, 最終的な 治療への一過程と考光るべきではないかと思われた。こ の考えのもとにスプリント治療の後, さらに関節円板を 安定させるために補経的対応を 5 症例に行った。これら の症例はすべて補経必要とする歯牙にう蝕があり, その ための治療も必要であったためである。しかしながら症 例 $3 ， 4$ はスプリント治療で関節円板が整位している靧 位を決定し，その顎位にて治療を行ったにもかかわら ず，補経処置後に関節円板が復位不能な転位を生じた。 また症例 5 は初診時，復位のない関節円板前方転位症例 であったが，徒手的円板整位術を行い，関節円板が復位 可能な状態で最小下顎前方位を決め補緅処置を行った が，処置後に再度関節円板が復位不能な転位を生じた。 残りの 2 例は処置後も関節円板は整位状態にあるが. そ のらち症例 2 は補綴治療後に咬筋の圧痛が増悪し, 前歯 部にわずかの開咬が生じた。咬筋のスパスムのため臼夹 部を支点とし，2次的に前歯部の開咬が生じたものと思 われる。このように処置後の問題を残す症例が存在する 理由は, 補経物の形態と咀嚼筋などの嚬機能との調和を 術前に把握し，決定することの困難性にあるのではない かと推測される，関節円板整位のために適切な咬合高径 が一時的に得られても, 重要な顎運動要素である咀嚼筋 との調和がとれない場合, 病態, 症状の再発あるいは増 悪などが起こりえるのではないかと思われた。

バイオネーターは歯牙を挺出させ, 結果的に下顎頭を 前下方に位置させ，関節円板にかかる荷重を減少させる ことになると思われる。ささらに夜間のみに装着させるこ とにより，変化した咬合関係を昼間の生活で機能的に適 応させるという特徵を有している。この点は前述の補経 治療が下顎位を一時点で決定することとは異なり, 若年 者の適正な下顎位を機能的に決定するものであると思わ れる、実際，バィオネーターによる治療を行った 4 例で は,すべて臼歯部の歯牙の挺出による咬合高径の増大が 認められたが，バイオネーター非装着時にも関節円板の 再転位はなく，また咬合の違和感，関節部痛，咀嚼筋痛 を訴える症例もなく, 顎機能と咬合の調和は十分に保た れていると思われた。歯牙の挺出量は, 顎関節症状扣よ び咀嚼筋症状を観察しながら検討した。
もともとバイオネーターは, 矯正科分野で臼歯部の歯 牙の挺出を図りアングル II 級咬合を改善する目的で使用 されるものであり ${ }^{21)}$, 過蓋咬合や下顎後退咬合を有する 円板動態異常の患者には被蓋の改善の意味でも特に有効 なものと思われる, 反面, 反対咬合者あるいは切端咬合 患者, 前歯部開咬, 前歯部ガイドの弱い患者では, さら にその咬合状態を悪化させ適応ではないと思われる。

下顎位の変化に対する形態学的な適応に関しては，実 験的に成長期に下顎を前方位に維持すると, 下顎頭の特 に後方部に軟骨の著明な増殖が認められ，その下部に骨 の添加が生じることが確かめられている ${ }^{22)}$. バィオネー ターによる治療も臼歯部歯牙の挺出により下顎を前方に 押し出す㗢きがあり，下顎頭も変化してゆく咬合に同調 しその形態を変化させ, 解剖学的にも適応してゆく可能 性のあることが推測される.

以上のようにバイオネーターは，咬合に関してスプリ ントを代表とする可逆的方法と, 補経治療を代表とする 非可逆的方法の中間的な位置にあるものと思える。著者 らの顎関節症に対するバィオネーター使用の意義は, 顎 関節の病態の改善を図るとともに種々の原因で妨げられ た咬合，顎顔面の発育を正常な方向へと促すことによっ て,さらに関節円板転位の再発を予防するといら機能的 な点にあると現時点ではとらえている．今回は整位可能 な関節円板前方転位症例に限ってバイオネーターを使用 したが，顎関節部にかかる荷重負担の減少を図る目的の ため，整位不能な関節円板転位症例，さらにその他の顎 関節症患者についても適応になるのではないかと思われ る.

結

語

19歳以下の顎関節症患者で, 関節円板前方転位と診断 され関節円板の整位が可能であった症例に対して，関節 円板の整位維持をはかるために行った各種の治療法の効 果について検討した。症例数は26症例でスプリントのみ 17 症例（下顎前方整位型スプリント11例，スタビライゼ ーションスプリント 6 例), スプリント治療の後, 補経 治療を行った症例 5 症例, スプリント治療の後, バイオ ネーター治療を行った症例 4 例であった。 またすべて 6 か月以上経過観察が可能であった。

\section{1. スプリント単独治療}

顎関節部の疼痛の除去には有効と思われたが，関節円 板の完全整位を得られた症例はなく，関節円板を安定さ せる最終治療が必要と思われた。

\section{2. 補緅治療}

関節円板の完全整位が 2 症例に認められた。しかしな がら 2 例で再発, 1 例で増悪が認められ，この 3 症例は 咬合と顎機能との不調和が原因と思われた。 


\section{3. バイオネーター治療}

すべての症例で咬合高径の増加が認められた，4例中 3 例は関節円板の完全整位が得られ，残る 1 例は両側の 復位のある関節円板前方転位であったが，片側で関節円 板の整位が得られた。治療中，関節部，咀嚼筋の疼痛を 訴える症例はなく，咬合と䫇機能は調和しているものと 思われた。

本論文の要旨は, 第 3 回日本枵関節 学 会 $(1990$ 年 7 月，東京）に沏いて発表した。

\section{引用文 献}

1）顎関節症に対する小委員会：顎関節疾患拉よび 顎関節症の分類案. 顎関節研究会誌 7: 135-136 1987.

2) 宮島智房，甲斐貞子，他：顎関節症患者の症型 分類による臨床統計的観察. 日外誌 37：8728841991.

3）迫田隅男, 芝 良祐, 他：顎関節症の臨床統計 的観察 過去10年間の臨床統計と予後調查. 日 顎誌 2: 79-88 1990.

4）村上賢一郎，瀬上夏樹，他：顎関節症 II 型への 臨床的対応と評価。岡達, 藍稔編: 顎 関節症治療のポイント 50 , 医菌薬出版, 東京, 1990, 56-64面.

5) 成 展熙, 高木律男, 他 : 症型分類（㴿関節研 究会提案）からみた顎関節症患者の臨床的検 討. 日外誌 35: 2958-2963 1989.

6) 甲斐貞子, 甲斐裕之, 他 : 若年者の顎関節症の 臨床統計的観察。日口外誌 投稿中.

7) Katzberg, R.W., Tallents, R.H., et al.: Internal derangements of the temporomandibular joint: Findings in the pediatric age group. Radiology 154: 125-127 1985.

8) 矢崎 篤, 和诰浩一, 他 : 若年者顎関節内障 (クリック）に対する下顎前方整位型スプリン 卜療法後の最終処置。口科誌 $37: 756-763$ 1988.

9) Lundh, H., Westessen, P., et al.: Anterior repositioning splint in the treatment of temporomandibular joints with reciprocal click- ing: Comparison with a flat occlusal splint and untreated control group. Oral Surg 60: 131-136 1985.

10) Clark, G.T.: The TMJ repositioning appliance: A technique for construction, insertion, and adjustment. J Craniomandib Pract 4: 37-46 1986.

11）丸山剛郎：顎関節症に対する補経学的フプロー 千。 日只外誌 33: 1079-1082 1987.

12）福岡保芳, 田口 望, 他: 若年発症顎関節症の 臨休研究一一般集団に打的顎関節症状に関す る検討一。 日外誌 33：485-493 1987.

13）古田 浩, 桑原未代子, 他: 若年発症顎関節症 の臨床研究一本症患者の䫟顔面頭蓋の形態に関 する検討一。 日外誌 33: 257-263 1987.

14）峰野泰久, 田口 望, 他: 若年発症顎関節症の

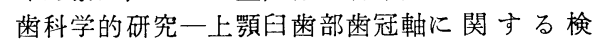
討一。 日外誌 33：1693-1697 1987.

15）峰野泰久, 田口 望, 他: 若年発症顎関節症の 歯科学的研究一咬合拉よび咬合素材に関する研 究一. 日外誌 32: 1908-1916 1986.

16) 田口望, 桑原未代子, 他: 若年発症顎関節症 の臨床研究一発症誘因・素因に関する検討一. 口科誌 35: 46-60 1986.

17）峰野泰久, 田口 望, 他: 若年発症顎関節症の

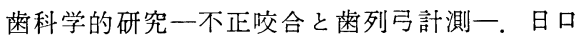
外誌 33: 649-656 1987.

18）成 辰熙, 五十嵐一男, 他：小児に発症した顎 関節症の臨床的検討。 日外誌 31 : 1809-1817 1985.

19）田口望: 若年者の診断と治療. 迷科ジャーナ ル 29: 495-509 1989.

20）和鴆浩一, 小飼英紀, 他：下顎前方整位型スプ リントの適応と治療効果一円板形態, 関節雑音 およびクリック期間との関連について一. 日顎 誌 2: 18-27 1990.

21）荻原和彦, 上原正実, 他：バイオネーターを用 いた一治験例に打ける下顎頭位の推移につい て. 小児歯誌 27: 1025-1034 1989.

22) McNamara, J.A. and Carlson, D.S.: Quantitative analysis of temporomandibular joint adaptations to protrusive function. Am J Orthod 76: 593-611 1979. 